DOI https://doi.org/10.18551/rjoas.2018-11.26

\title{
INFORMATION SYSTEMS SUCCESS DIMENSION IN INDONESIA ONLINE TRAVEL AGENCY INDUSTRY
}

\author{
Kustiwi Irda Agustin \\ Department of Accounting, University of Airlangga, Surabaya, Indonesia \\ E-mail: irdaagustin@gmail.com
}

\begin{abstract}
Technological developments allow us to carry out daily activities makes information more value expensive, quickly and easily obtained. Information technology is needed to obtain, manage, send and or share information. Online travel agency (OTA) industry are a part of information system that used application (website, application store, IOS) where an activity is supported by features classified according to needs. Others, information systems support is getting cheaper and easier such as in gadget that offers ease of doing activities that generate interest. Traveloka, Tiket.com, and Pegi-pegi are online travel agent applications that offer cheap, fast and supported by user friendly features. The base theory used to measure this information systems success is The DeLone and McLean Model. Descriptive quantitative method is used in research to describe a condition that includes 100 respondents which is ever use online travel agent application, then using purposive sampling technique for data collection. This paper result consists the high quality of system are obtained by Tiket.com, the quality of information obtained by Tiket.com, the quality of services obtained by Pegi-pegi, the users and the highest quality quality obtained by Traveloka, and the net benefits for users obtained by Tiket.com.
\end{abstract}

\section{KEY WORDS}

Information systems, success, Indonesia, online travel agency, industry.

The development of information technology is a driving factor for electronic-business, commonly known as e-businesses. A company that uses the internet network can establish relationships with business partners or consumers more efficiently. Until now the internet is an ideal infrastructure for running e-business based businesses so that the term e-business becomes synonymous with running a business on the internet. This statement is supported by Sid L. Huff, et.al (2000) which explains that e-business is an activity related to information and communication technology (ICT) both between organizations and between organizations to consumers.

Smart technology has provided extraordinary flexibility for organizations to be creative in various activities, including travel industry in Indonesia. So that there is an increase in demand in the field of online travel agencies (OTA) which have shifted traditional concepts into more modern concepts. Some online travel agents engaged in the online travel industry in Indonesia, namely Traveloka, Tiket.com, Pegi-pegi, and many others.

An interesting fact is online travel agent industry is growing so fast through an important role of technology. Online travel agency relies on internet services to market their services, including for the use of their services. This application used by website, application store, ios where an activity is supported by an application that has features that are classified according to needs. The other hand, technology support is getting cheaper and easier, with such phenomena, it certainly offers convenience in carrying out activities that generate interest. Traveloka, Tiket.com, and Pegi-pegi are parts of online travel agency that offer cheap and fast services supported by easy-to-use information systems. It was seen from the data of online travel agencies survey conducted by Dailysocial in 2018 that respondents who used online travel agency services in Indonesia reached $71.44 \%$.

A technology that makes it easy for people to carry out daily activities, because information is quickly and easily obtained. So it is necessary to update technology to get, manage, send, and or share information. The extent to which information will continue to 
consistently meet the requirements and expectations of all people who need information. The concept that is linked to information that uses data which is then processed so that it gives meaning to the recipient and is assisted by the application media.

The topic about successful information systems have been widely researched and produced several models. This system has two characteristics including mandatory and voluntary. The models that are part of a successful information system include the Unified theory of acceptance and use of technology-UTAUT (Morris, 2003), the DeLone and McLean-D \& M Model (Delone and Mclean, 2003), and the Wixom and Todd Models (Wixom and Todd, 2003). However, this research focuses more on using the Delone and McLean model as a basic theory. Like the research conducted by Dorobat (2014) which measures information systems at the University using e-learning technology to see its information system success. Furthermore, the research of Lee and Yu (2012) and Zaied (2012) analyzed the company's management information system by using this model so that it could be done for decision making.

The online travel agency industry is positively welcomed by the community because it is an alternative travel agent that is efficient and effective. Its existence is very helpful in facilitating users. Every user who will use online travel agency services. Traveloka, Tiket.com, and Pegi-pegi are the three best startup sites engaged in online travel agency industry in Indonesia. This statement is supported on the Miner8.com site (2017), the three types of startup can facilitate users in finding accommodation on a trip such as plane tickets, trains, to hotel bookings. This can be done either through the site / website or can download the application via Playstore and Apple Store. Simple appearance with the main functions displayed on the main menu, of course lay people can easily understand. The features found on Traveloka, Tiket.com, and Pegi-pegi startups can make it easier for users to carry out activities, in this technological era it can increase interest in service users. As for what determines the success of the information system according to Delone and Mclean (2003), covers 6 important dimensions. The dimensions include system quality, information quality, usage, user satisfaction, service quality and net benefits (individual impact and organizational impact).

The case background of this research is to analyze information systems at Traveloka, Tiket.com, and Pegi-pegi startups both websites and mobile applications. This online travel agency industry can be accepted by the public if it have a good system quality, information quality that can meet user needs, service quality can help users, users of services most often used, user satisfaction to meet consumer expectations, and generate net benefits overall (both individually and organizationally). Thus, this research is more focused on explaining the e-business system implemented by online travel agency industry and the success of information systems both website and mobile applications used in the online travel agency industry by being limited by the three types of startups, namely Traveloka, Tiket.com, and Pegi-pegi.

Based on the explanation above, the researcher intends to raise these problems as research material. The title is "Information Systems Success Dimension in Indonesia Online Travel Agency (OTA) Industry".

\section{THEORY AND HYPOTHESES DEVELOPMENT}

Information Systems. According to Laudon (2012: 16) explains that the definition of an information system is a combination of several interrelated components that are useful for collecting, processing, and finally conveying information that can be used as an option to make decisions both organizations and companies.

Supported by the statement of Whitten, Bentley, and Ditman (2009: 10), the understanding of information systems is the result of the interaction of various parties such as people, data, and processed to become information technology needed by an agency.

Actually there are still many information system definitions put forward by several other authors, but indirectly this system has an important role for users. This is because the information system is part of several systems that are collected, processed, and issued into 
output in the form of information that is useful for internal and external in taking an action for the survival of an organization or individual.

Besides that, information system has eight unique dimensions $s$ as stated by Sutabri (2012), it is includes: (1) Components, (2) Boundary, (3) Environment, (4) Interface, (5) Input, (6) Output, (7) Process, and (8) Objective.

DeLone and McLane Information System Success Model. Based on research conducted by Jogiyanto (2007), DeLone and McLane Information System Success Model is a model form that has been expanded from previous research. The development of this model consists of several dimensions that will be described below:

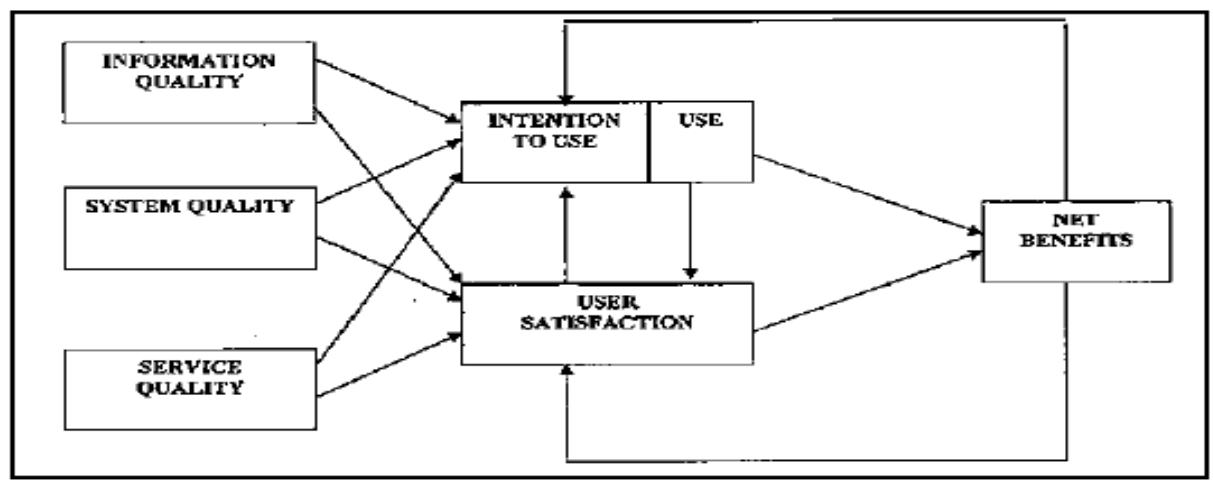

Figure 1 - The D\&M IS Model (Source: DeLone and McLane, 2003)

The history of this developed model was carried out in 20003. Researchers DeLone and $\mathrm{E}$. McLean updated the model to measure the quality of information systems that resulted from contributions from several previous studies and due to changes in role and handling of late information systems. DeLone and McLean renewed it and called it a System Success Model $D$ \& M Model Information. According to $D \& M$, there are six dimensions of factors in the measurement of this model, there are:

- System Quality. The first dimension of this model is system quality. It is used in knowing the characteristics of the application of information technology itself. So that it can be said how far the quality and performance of the system. As for examples such as system reliability, ease of use, speed of access, system flexibility and security.

- Information Quality. Information quality is the second dimension of this model that has a function as a tool to measure the output of information systems. This must be relevant, complete and easy to understand.

- Service Quality. Service quality has the main function that can be used for marketing research of an organization. According to Pasaruraman, et.al. in Purnama (Purnama, 2006: 19), explaining about service quality is closely related to perceptions of the level of consumer expectations. So if the marketing of a company knows the needs and desires of consumers, then it can create profits.

- Use. The fourth dimension in the D \& M model is use, where the discussion is broad as it covers the entire information retrieval system and interaction through navigation in the application. Today, the dimension of use has undergone a shift in meaning due to having a simple meaning even though it has a very broad role.

- User Satisfaction. User satisfaction connected to user satisfaction in utilizing the information system application features. According to Somers et.al. (2005: 597), end user satisfaction is an effective attitude that can be felt directly by users after using technology-based systems.

- Net Benefit. Net benefits are the last dimension of this model. This dimension is a collection of several impacts resulting from information systems, namely individual impacts and organizational impacts. When examined more deeply, the impact of this merger is very broad because it can occur between organizations, organizations to 
consumers, to between countries. So that a model is needed for the parsimony system to occur.

\section{METHODS OF RESEARCH}

This study uses a quantitative research that is descriptive approach. According to Sugiyono (2009), quantitative approach means a research approach that is done by processing and presenting data by calculating statistics that involve numbers or scores so that the researcher can make decisions objectively. It is used because of relevancy to the formulation of the problem to be answered in this paper, which is trying to describe the comparison of information system success in OTA industry.

The total sample of this paper takes 100 consumers who ever use online travel agency industry application system (Traveloka, Tiket.com, and Pegi-pegi). Purposive sampling technique is used for data collection. This is obtained through questionnaires and measured by a likert scale. For data processing, this study chose measurement tools namely is SPSS. Generalization results are described descriptively then analyzed to find out the comparison of information system success in online travel agency industry in Indonesia.

The measurement tool used in this study is a five likert scale. There are many function of this scale likes used to measure attitudes, opinions and perceptions of a person or community regarding a phenomenon. A five likert scale options are usually provided with a format such as a value of 1 which is strongly disagree to the highest value of 5 which is strongly agreed. To determine the category of an answer whether high, medium, low, first, the interval class is determined.

The upper category interval all respondents answers to each variable include:

- Very high category values $=4,21-5,00$;

- High category values $=3,41-4,20$;

- Medium category value $=2,61-3,40$;

- Low category value $=1,81-2,60$;

- Very low category values $=1,00-1,80$.

To be able to determine the respondent's answer classified, the total value of the variable will be determined on average by dividing the number of questions. From the results of the division, the respondent's answers will be included in the same category.

\section{RESULTS AND DISCUSSION}

The total sample used in this study was 100 respondents, which are users who ever used online travel agency online likes Traveloka, Tiket.com, and/or Pegi-pegi, were conducted by purposive sampling technique method. The selected measuring instrument is SPSS, this function as a processing tool and analyzes the data that has been collected. The following are the results of descriptive and analyze data that will be presented, there are:

A. Respondents Description. Overall about respondents' description of this paper can be seen in the table below as follows:

Table 1 - Respondents Description

\begin{tabular}{|c|l|l|c|}
\hline No. & \multicolumn{1}{|c|}{ Users Identity } & Total \\
\hline \multirow{4}{*}{1} & \multirow{3}{*}{ Education } & 1. Junior High School & - \\
& & 2. Senior High School & 4 \\
& & 3. Bachelor Degree & 58 \\
& & 4. Master Degree & $\underline{38}$ \\
2 & Total & 100 \\
\hline \multirow{3}{*}{ Online Travel Agency (OTA) } & 1. Traveloka & 34 \\
& & 2. Tiket.com & 33 \\
& 3. Pegi-pegi & $\underline{33}$ \\
\hline
\end{tabular}


Table 1 shows the profile description of respondents who use online travel agency which consists of the highest number of education items, namely bachelor degree of 58 users. In addition, online travel agency items that are widely used are Traveloka as many as 34 users.

B. Validity and Reliability Test. The results of the validity of the question instrument from DeLone and McLane Information System Success Model consists of system quality (21 questions), information quality (15 questions), service quality (5 questions), use (7 questions), users satisfaction (6 questions), and net benefits (6 questions). Based on the results of the validity of 100 respondents on the instrument the question used is declared valid because $r$ counts from these variables is greater than $r$ table.

The instrument can said to be reliable if Cronbach's Alpha> 0.60. The reliability test results can be summarized briefly in table 2 as follows:

Table 2 - Reliability Test

\begin{tabular}{|c|c|c|c|}
\hline Classification & Cronbach's Alpha & Limit & Notes \\
\hline Quality Systems & 0.942 & 0.60 & Reliable \\
\hline Quality Information & 0.958 & 0.60 & Reliable \\
\hline Service quality & 0,813 & 0.60 & Reliable \\
\hline Use & 0.784 & 0.60 & Reliable \\
\hline User satisfaction & 0,782 & 0.60 & Reliable \\
\hline Net benefits & 0.931 & 0.60 & Reliable \\
\hline
\end{tabular}

In table 2 above, the data obtained from the study showed that all indicators obtained the value of Cronbach's alpha above the value of 0.60 , so it can be concluded that all variables proved reliable.

C. DeLone and McLane Information System Success Model:

C.1. Quality System. Quality system is first variable of this model information systems success, has the advantage of being able to measure the characteristics of online travel agent applications both on websites and mobile phones such as system reliability, ease of use, speed of access, system flexibility and security. Following are the results of the table presented:

Table 3 - Quality System

\begin{tabular}{|c|c|c|c|c|}
\hline $\mathrm{n} / \mathrm{n}$ & $\mathrm{N}$ & Min & Max & Mean \\
\hline Traveloka & 34 & 61 & 105 & 83.71 \\
Tiket.com & 33 & 63 & 105 & 86.36 \\
Pegi-pegi & 33 & 58 & 105 & 82.94 \\
\hline
\end{tabular}

We can see at Table 3 about Quality system, Tiket.com has the first rank with 86.36, Traveloka with 83.71, and Pegi-pegi with 82.94. It means Tiket.com has more advantages in the quality system dimension compared to others.

C.2. Quality Information. Second variable of information systems success model is quality information. This system can be said to be success if it is able to be measured, such as must be relevant, reliable, complete, easy to understand and user friendly. Hereby the table of quality information:

Table 4 - Quality Information

\begin{tabular}{|c|c|c|c|c|}
\hline $\mathrm{n} / \mathrm{n}$ & $\mathrm{N}$ & Min & Max & Mean \\
\hline Traveloka & 34 & 39 & 75 & 61,82 \\
Tiket.com & 33 & 45 & 75 & 62.94 \\
Pegi-pegi & 33 & 40 & 75 & 60.82 \\
\hline
\end{tabular}

Based on table 4, Pegi-pegi gets the last rank with 60.82, Traveloka with 61.82 , and Tiket.com with 62.94. This reason because Tiket.com have the quality of information presented (website and mobile smartphone) are more relevant and reliable for all users such as for all genders, age groups, and education. 
C.3. Quality of Service. Quality of Service is a part of information systems that can be used in marketing research. This is because it is directly related to the needs and desires of customers to be able to provide the services expected by customers. Below is the test table:

Table 5 - Quality of service

\begin{tabular}{|c|c|c|c|c|}
\hline $\mathrm{n} / \mathrm{n}$ & $\mathrm{N}$ & Min & Max & Mean \\
\hline Traveloka & 34 & 12 & 25 & 20.18 \\
Tiket.com & 33 & 13 & 25 & 19.48 \\
Pegi-pegi & 33 & 19 & 49 & 37.52 \\
\hline
\end{tabular}

Table 5 about quality of service explaned that the mean value obtained Tiket.com is 19.48, Traveloka is 20.18, and Pegi-pegi is 37.52. From the results, Pegi-pegi gets the first rank that can be said that the quality of service is controlled by this startup.

C.4. Users. Fourth variable is users; it is quite significant to provide overall information retrieval systems as well as interaction with navigation in online application. We can see the results of the table below:

Table 6 - Users

\begin{tabular}{|c|c|c|c|c|}
\hline $\mathrm{n} / \mathrm{n}$ & $\mathrm{N}$ & Min & Max & Mean \\
\hline Traveloka & 34 & 24 & 35 & 29.82 \\
Tiket.com & 33 & 18 & 35 & 24.97 \\
Pegi-pegi & 33 & 18 & 35 & 23.70 \\
\hline
\end{tabular}

Table 6 can be shown that the lowest mean value obtained is Pegi-pegi 23.70, Tiket.com earned 24.97, and Traveloka with 29.82 Grab, and the highest mean value obtained Gojek 29.82. So, many consumers that use Traveloka as their choice to do their travel.

C.5. User Quality. The other part of information systems success is user quality. This dimension can be said to be successful if it is able to provide satisfaction to the consumens through the quality of user satisfaction in the application. The results are seen through the table:

Table 7 - User Quality

\begin{tabular}{|c|c|c|c|c|}
\hline $\mathrm{n} / \mathrm{n}$ & $\mathrm{N}$ & Min & Max & Mean \\
\hline Traveloka & 34 & 19 & 30 & 25.32 \\
Tiket.com & 33 & 17 & 30 & 23.52 \\
Pegi-pegi & 33 & 12 & 30 & 23.09 \\
\hline
\end{tabular}

We can know that Table 7 consist of the lowest mean value obtained is Pegi-pegi with 23.09, Tiket.com with 2352, last the highest one is Traveloka with 25.32. Traveloka has the highest score in user quality variable.

C.6. Net Benefits. Last but not least, net benefits are the sixth dimension of this model. It can be said that important variable for the information system, because it is related for long term benefits. This result can be seen at table:

Table 8 - Net Benefits

\begin{tabular}{|c|c|c|c|c|}
\hline $\mathrm{n} / \mathrm{n}$ & $\mathrm{N}$ & Min & Max & Mean \\
\hline Traveloka & 34 & 19 & 30 & 25.12 \\
Tiket.com & 33 & 18 & 30 & 25.45 \\
Pegi-pegi & 33 & 14 & 30 & 25.09 \\
\hline
\end{tabular}

Based on Table 8 it can be seen that the net benefits of the lowest mean value obtained is Pegi-pegi with 25.09, Traveloka is the second one with 25.12, and the highest mean value obtained is Tiket.com with 25.45 . From the results above, it can be said that the net benefit is controlled by Tiket.com as having the highest. 


\section{CONCLUSION AND SUGGESTIONS}

Based on research that has been explored more deeply about the comparison of information systems success systems in the online travel agent industry in Indonesia, the authors can conclude that the quality of information on applications both online and mobile includes system quality, information quality, service quality, users, user quality and net benefits has been done optimally by the online travel agent industry. The results of the high quality of the system are obtained by Tiket.com, the quality of information obtained by Tiket.com, the quality of service obtained by Pegi-pegi, the highest user and quality of results obtained by Traveloka, the latest regarding the net benefits for users obtained by Tiket.com.

As for this study has limitations so that it can be used better in research in the field of online travel agents in the future, among others: (1) Can be added some variables that are adjusted to the conditions needed. This is more and more variables, expected to be more relevant and reliable. (2) Although it has fulfilled the respondent's requirements according to the SSS test tool, it is expected to be able to receive more feedback or input from respondents so that the results can be used widely.

For the sake of further research perfection, it is necessary to consider several variables that can be used to improve the validity of research results, which can be applied to ecommerce branches or other subjects, such as online shopping applications, online transportation applications, and many others.

\section{REFERENCES}

1. Zaied A. (2012). An Integrated Success Model for Evaluating Information System in Public Sectors. Journal of Emerging Trends in Computing and Information Sciences, Vol. 3, Pp. 814.

2. Beatley, Lonni D. and Jeffrey L. Whitten. (2007). System Analysis and Design For The Global Enterprise. Seventh Edition. New York: Mc Graw-Hill.

3. H. Wixom and P. A. Todd. (2005). A Theoretical Integration of User Satisfaction And Technology Acceptance. Information System Research, Vol. 16.

4. Chin WW. (1998. The Partial Least Squares Approach For Structural Equation Modeling. In: Marcoulides GA, Editor. Modern methods for Business Research. New York: Lawrence Erlbaum Associates Publishers: pp. 295 \pm 336 .

5. Dailysocial.co.id. (2018). Laporan Dailysocial Survey Online Travel Agencies OTA 2018. Retrieved From https://dailysocial.id/post/laporan-dailysocial-survey-online-travelagencies-ota-2018.

6. DeLone, W H, and McLean, E.R. (1992). Information System Success: The Quest For The Dependent Variable. Information System Research 3, No. 1 (1992): 60-90.

7. DeLone, W. H., and McLane, E. R. (2003). The DeLone and McLane Model of Information System Success A Ten-Year Update. Journal of Management Information System, Vol.19, No.4, 9-30.

8. Hair, J, W Black, B Babin, R Anderson, and R Tatham. (2006). Multivariate Data Analysis. New Jersey: Prentice Hall.

9. Dorobaţ I. (2014). Models for Measuring E-Learning Success in Universities: A Literature Review. Informatica Economica, Vol. 18, Pp. 77.

10. Jogiyanto, H. (2007). Model Kesuksesan Sistem Teknologi Informasi. Yogyakarta: Andi.

11. Laudon, Kenneth C., dan Jane P. Laudon, (2012). Management System: Managing the Digital Firm Twelfth Edition. New Jersey: Prentice Hall.

12. Miner8.com. (2017). 12 Situs Untuk Booking Hotel dan Pesawat Online Dengan Harga Terbaik! Retrieved from http://miner8.com/id/14572.

13. Morris, M. G., et al. (2003). User Acceptance of Information Technology: Toward A Unified View. MIS Quarterly, Vol. 27, No. 3, Pp. 425-478.

14. Purnama, N. (2006). Manajemen Kualitas (Edisi Pertama). Yogyakarta: Ekonisia.

15. Sid L. Huff, et.al. (2000). Cases in Electronic Commerce. McGraw-Hill. 
16. Somers, T.M., Nelson, K., and Karimi, J. (2003). Confirmatory Factor Analysis of the EndUser Computing Satisfaction Instrument: Replication within an ERP Domain. Decision Science, 34(3): 595-621

17. Sugiyono. (2009). Quantitative and Qualitative Research Methods. CV. Alfabeta: Bandung

18. Sutabri, Tata. (2012). Analisis Sistem Informasi. Yogyakarta: Andi.

19. Sutabri, Tata. (2012). Konsep Sistem Informasi. Yogyakarta: Andi.

20. S.-K. Lee and J.-H. Yu. (2012)Success model of Project Management Information System in Management. Automation in Construction, Vol. 25, Pp. 82-93.

21. Whitten, Jeffrey L., Lonnie D. Bentley, Kevin C. Ditman. (2004). Systems Analysis and Design Method. 6 Edition. Mcgraw-Hill. 